\title{
EVALUATION OF MANAGEMENT PROGRAM AT INTEGRATED ISLAMIC ELEMENTARY SCHOOL (SDIT AL-HIKMAH JAKARTA)
}

\section{KHASANAH}

\begin{abstract}
Khasanah Universitas Ibn Khaldun SDIT al-Hikmah is an integrated Islamic Elementary School for which aim is to integrate the value and Islamic Email norms into special character building using effective khasanahrajali@yahoo.co.id approach. This research is aimed to gain objective information and to investigate how effective the management program of SDIT al-Hikmah Jakarta. This research is an evaluation research using CIPP model, which includes 4 (four) evaluation components, which are: (1) Context (2) Input (3) Process (4) Product. The research method use in this research is case study based on qualitative research. The data collection are compiled using document study, interview, observation and questioner. The data will be analyzed in descriptive method, which data will be examine by comparing the examine data with selective objective criteria. Afterwards, the researcher will conclude the decisions on every evaluation phases. The findings on evaluation reveals that SDIT al-Hikmah is needed for its achievement to implant the good education for the children. Furthermore, there are still some aspects that needs to be improved. This research also recommends that SDIT al-Hikmah and Jaringan Sekolah Islam Terpadu (Integrated Islamic School Network) to improve the program with some selective criteria

Keywords : evaluation program, management, islamic school
\end{abstract}


A. Introduction

Education has several critical roles in a nation's development. Improvement of education quality will contribute to the improvement of human resource quality and will in turn has impact on development it self. This is in line with the long life education and education for all as declared by the UNESCO.

Islamic educational institutions all over the country have given significant contribution for the advancement of education in this country. However, there are still separate management practices between general sciences and religious sciences. Integration between these two will need to be done without sacrificing the specialization that has become the nature of the modern community. integration of general and religious sciences in the next phase will generate the concept of knowledge Islamization, a currently ongoing discussion. Islamization of knowledge, according to Kuntowijoyo as cited by Nata ( (2007: 87-88) is a very significant answer to the current challenge in education, a dualism between general knowledge/science and religious knowledge/science. ${ }^{1}$

The existence of Integrated Islamic School since the 1990s, according to Alydroes (2008:1) has been trying to give solution on the integration of these concepts, Islamization is a key factor to differentiate Islamic school with other schools. Within the learning process, the main purpose of islamization is to form integral awareness and pattern of thinking in Islamic perspective. Students are guided to think and understand the whole natural phenomena surrounding them and all their accompanying problems, including all their dynamics as things that are inseparable from the role of Allah SWT. Through the islamization of learning, strong emotional bonds among the themes, students, and Islamic values will be forged. ${ }^{2}$

Therefore, a comprehensive evaluation on the management program of Integrated Islamic Schools, especially on Integrated Islamic Elementary School (SDIT) will give significant contributions

\footnotetext{
Abududdin Nata. Manajemen Pendidikan, Mengatasi Kelemahan Pendidikan Islam Di Indonesia. (Jakarta: Kencana Prenada Media Grup, 2007), pp. 87-88.

${ }^{2}$ Fahmi Alaydroes, Latar Belakang, Visi dan Format Sekolah Terpadu, http;//www.jsit.or.oid, p. 1.
} 
Evaluation of Management:...(Khasanah)

as the basis for the implementation of future programs and activities.

The problems that will be investigated in this research are formulated as follow:

1. How are the suitability of SDIT program with the context of government policy and SDIT, objectives of SDIT, and public demands on SDIT?

2. How are the suitability of SDIT input with the standard input of programs that consists of students, parents' support ability, school financing, curriculum, teachers and education staffs, and school administration?

3. How are the process suitability in SDIT with the standard process that consists of designing learning process, implementation of learning process, learning assessment, personal development activities/extracurricular activities, supervision and evaluation?

4. To what extent is the success of SDIT management from the output (learners) perspective following their enrolment in this program, academically and non-academically?

\section{B. Discussion of Research}

\section{Program Evaluation}

Evaluation has a very important role in every aspect of human activities due to its role to determine effectiveness and continuation of an activity, hence, necessary improvement can be done in time.

Evaluation also useful for decision makers to select from several available alternatives, as Worthen and Sanders (1987:81) describe that evaluation as a process to ensure a decision, to select appropriate information, to collect, and to analyze information, thus, it can provide summary of data to make decision out of several available alternatives. ${ }^{3}$ Along with this, Cronbach and Stufflebeam (2006:3) as Arikunto cites that evaluation process is not only measure the extent of objective attainment, but also use to make decision. ${ }^{4}$

Grondlund (1990 : 5) in his book, Measurement and Evaluation in Teaching, states that "evaluation is the systematic process of collecting,

3 Blaine R. Worthen dan James R Sanders, Educational Evaluation, Alternative Approaches and Practical Guidelines ( New York and London : Longman Inc:1987), p. 81.

4 Suharsimi Arikunto, Dasar-Dasar Evaluasi Pendidikan (Jakarta: Bumi Aksara, 2006), p. 3. 
analyzing and interpreting information to determine the extent to which pupils achieving instructional objects. ${ }^{5}$ It can be implied that evaluation is a process to collect information, systematically and objectively, to make decision of an object.

On the other hand, program can be generally defined as plan. If this program is directly related with evaluation program, then this program is defined as a unit of activities, which are realization or implementation of a policy, that is held in cycles, and is implemented within organization that involves a group of people. Arikunto and Safruddin (2004; 5) reveal that program is a system. Meanwhile, a system is an unity of several program components that are interwoven and cooperate one another in order to attain the objectives set within the system. ${ }^{6}$ Program consists of components that are complementing each other for the success of a program. As Arikunto and Safruddin (2004: 7) state that program evaluation is an effort to find out the

5 Norman E. Groundlund and Robert Linn, Measurement and Evaluation in Teaching (New York: MacMillan Publising Company, 1990), p. 5.

${ }^{6}$ Suharsimi Arikunto dan Cepi Safruddin Abdul jabbar, Evaluasi Program Pendidikan, Pedoman Teoritis Praktis Bagi Praktisi Pendidikan (Jakarta: Bumi Aksara, 2004), p. 5. extent of a policy can be properly carried out and to find out the effectiveness of each of its components. ${ }^{7}$

Based on the explanation above, it can be concluded that program evaluation is an effort to collect, compile, process, and analyze facts, data, and information on a program, an office, a school, an organization or an institution as the basis of decision making on that specific program, whether to be carried on or terminated.

\section{Definition of Integrated Islamic School (SIT)}

In its application, Integrated Islamic School as defined by JSIT team (2006: 58) as school that implements approaches that integrates the general education and religious indication in a curriculum. Through this approach, all the subjects and all of the school activities are tied to the framework of Islamic values. ${ }^{8}$ There are no dichotomies, no secularization where Islamic teachings are taught separately from the context of present and future lives. General subjects, such as, mathematics, natural sciences, social

${ }^{7}$ lbid., p.7

8JSIT Indonesia, Sekolah Islam Terpadu Konsep dan Aplikasinya., (Bandung: Syamil Cipta Media, Bandung, 2006), p. 58. 
sciences, languages, sports and health, and other skills are framed within the Islamic values and guidance. Meanwhile, in religious subjects, curriculum are enriched with current contexts and benefits.

Taking in mind the definitions above, a generic but comprehensive definition of Integrated Islamic School can be made, that Integrated Islamic Schol is an Islamic school that is conducted by integrating the Islamic values and teaching within the curriculum and using the effective and optimal learning approaches along with the cooperation among teachers, parents, and community in developing the students' characters and competencies.

\section{Evaluation Method}

This research is an evaluative research focuses on investigating the effectiveness of programs at SDIT and their suitability with the output of the program. In this research, CIPP model of evaluation is used, in which, as Popham (1974:34) reveal that there are four components of this model, namely: contexts, input, process, and product. The advantages of this product is that it gives a comprehensive study of an observed social phenomenon. CIPP model is decision oriented. ${ }^{9}$

In order to enable a program evaluation, the focuses within those four components as used in this research can be seen in the following table :

Table 1. Focus of Evaluation

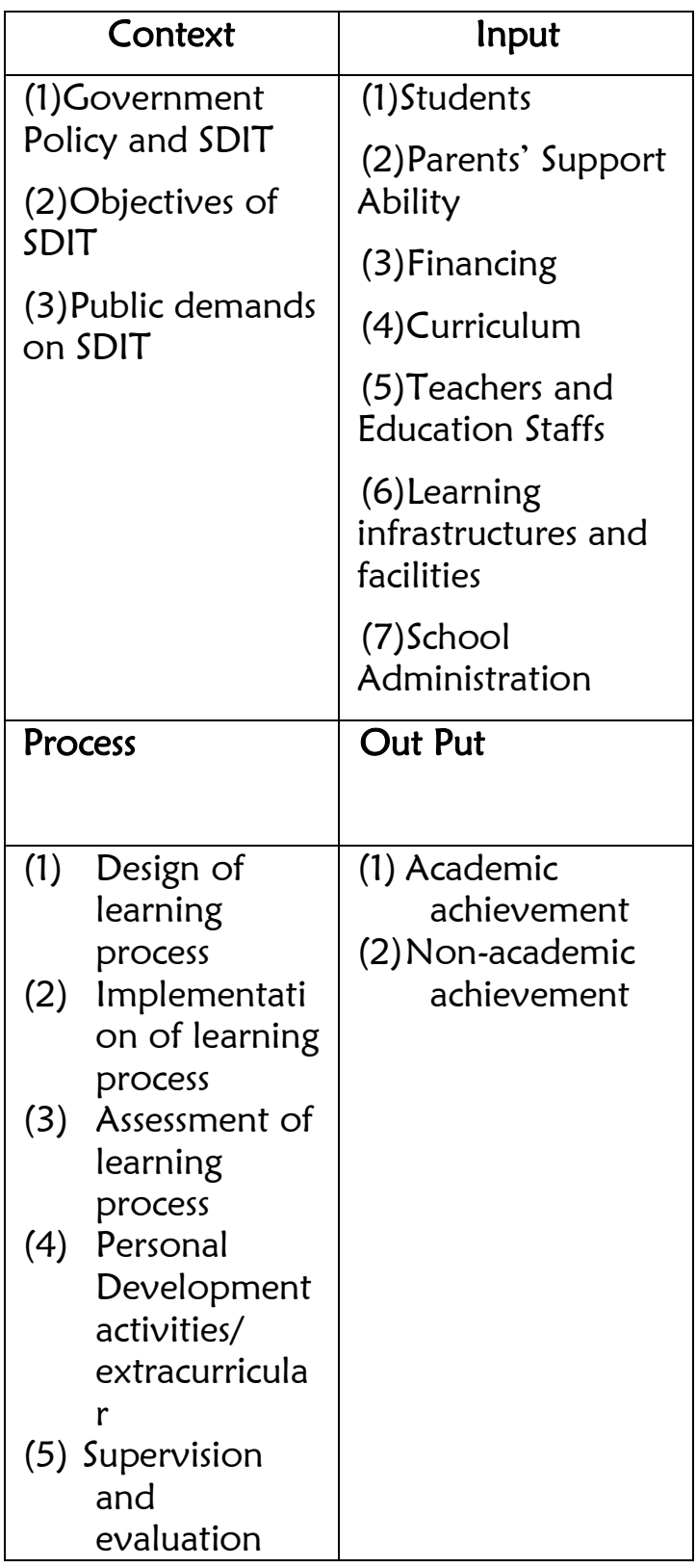

9 W. James Popham, Educational Evaluation (New Jersey: Prentice-Hal Inc, 1974), p. 34. 
Data collection is aimed at government and JSIT (Integrated Islamic describing the real condition in the field, School Network) which are later compared with the The data, data source, and standard of elementary school indicators in this research are available in management composed by the the following table:

Table 2. Data Source of Context

\begin{tabular}{|l|l|l|}
\hline \multicolumn{1}{|c|}{ ASPECTS } & \multicolumn{1}{|c|}{ INDICATORS } & \multicolumn{1}{|c|}{$\begin{array}{c}\text { DATA SOURCE/ } \\
\text { DATA COLLETION } \\
\text { INSTRUMENTS }\end{array}$} \\
\hline \multicolumn{1}{|c|}{ (1) } & \multicolumn{1}{|c|}{ (2) } & \multicolumn{1}{|c|}{ CONTEXT } \\
\hline $\begin{array}{l}\text { (1) Government } \\
\text { Policy and SDIT } \\
\text { policy related to education } \\
1.2 \quad \text { Has policy document } \\
\text { On SDIT }\end{array}$ & $\begin{array}{l}\text { School Principal / } \\
\text { Document Analysis }\end{array}$ \\
\hline $\begin{array}{l}\text { (2) Objectives of } \\
\text { SDIT }\end{array}$ & $\begin{array}{l}2.1 \text { Has clear formulation of } \\
\text { SDIT objectives } \\
2.2 \quad \text { Tries to spread the } \\
\text { objectives of SDIT }\end{array}$ & $\begin{array}{l}\text { School Principal, Parents / } \\
\text { Document Analysis, } \\
\text { Interview }\end{array}$ \\
\hline $\begin{array}{l}\text { (3) Public demand } \\
\text { on SDIT }\end{array}$ & $\begin{array}{l}\text { 3.1 there is a relevance of } \\
\text { SDIT existence with public } \\
\text { needs }\end{array}$ & $\begin{array}{l}\text { Schoo Principal, Parents / } \\
\text { Questionaire, } \\
\text { analysis }\end{array}$ \\
\hline
\end{tabular}

Table. 3 Data Source of Input

\begin{tabular}{|c|c|c|}
\hline ASPECTS & INDICATORS & $\begin{array}{l}\text { DATA SOURCE/ } \\
\text { DATA COLLECTION } \\
\text { INSTRUMENTS }\end{array}$ \\
\hline (1) & (2) & (3) \\
\hline \multicolumn{3}{|c|}{ INPUT } \\
\hline (1) Student & $\begin{array}{l}\text { 1.1 There is a selection for } \\
\text { admission of new students }\end{array}$ & $\begin{array}{l}\text { School principal / } \\
\text { Document analysis, } \\
\text { questionnaire }\end{array}$ \\
\hline $\begin{array}{l}\text { (2) Parents' support } \\
\text { ability }\end{array}$ & $\begin{array}{l}\text { 2.1 Sufficient socio-economic } \\
\text { condition of parents } \\
\text { 2.2 Parental participation in } \\
\text { learning process }\end{array}$ & $\begin{array}{l}\text { Parents, Students / } \\
\text { Questionnaire }\end{array}$ \\
\hline
\end{tabular}


Evaluation of Management:...(Khasanah)

\begin{tabular}{|l|l|l|}
\hline (1) School financing & $\begin{array}{l}3.1 \text { sufficient funding } \\
\text { allocation for routine } \\
\text { expenditure and } \\
\text { development }\end{array}$ & School Principal / \\
Questionnaire \\
\hline $\begin{array}{l}\text { (4) Curriculum on } \\
\text { level (KTSP) }\end{array}$ & $\begin{array}{l}4.1 \text { Has KTSP document } \\
4.2 \text { development of syllabus } \\
\text { and lesson plan (RPP) } \\
4.3 \text { accomodating local } \\
\text { content } \\
4.4 \text { accomodating personal } \\
\text { development activities }\end{array}$ & $\begin{array}{l}\text { School principal, Teachers / } \\
\text { goideline, questionnaire }\end{array}$ \\
\hline $\begin{array}{l}\text { (5) teacher and } \\
\text { education staff }\end{array}$ & $\begin{array}{l}5.1 \text { Appropriate ratio of } \\
\text { numbers of teachers and } \\
\text { students } \\
5.2 \text { sufficient numbers of } \\
\text { education staffs }\end{array}$ & $\begin{array}{l}\text { School Principal / } \\
\text { Questionaire, Document } \\
\text { analysis }\end{array}$ \\
\hline $\begin{array}{l}\text { (6) learning } \\
\text { infrastructure and } \\
\text { facilities }\end{array}$ & $\begin{array}{l}6.1 \text { sufficient learning } \\
\text { infrastructures and facilities }\end{array}$ & School / \\
\hline $\begin{array}{l}\text { (7) School } \\
\text { Administration }\end{array}$ & $\begin{array}{l}7.1 \text { Ample school } \\
\text { administration }\end{array}$ & $\begin{array}{l}\text { Administration Unit / } \\
\text { Observation, Questionnaire }\end{array}$ \\
\hline
\end{tabular}

Table 4. Data Source of Process

\begin{tabular}{|c|c|c|}
\hline ASPECTS & INDICATORS & $\begin{array}{l}\text { DATA SOURCE/ } \\
\text { DATA COLLECTION } \\
\text { INSTRUMENTS }\end{array}$ \\
\hline (1) & (2) & (3) \\
\hline \multicolumn{3}{|c|}{ PROCESS } \\
\hline $\begin{array}{l}\text { (1) Designing } \\
\text { Learning Process }\end{array}$ & $\begin{array}{l}1.1 \text { development of syllabus } \\
1.2 \text { development of lesson } \\
\text { plan (RPP) }\end{array}$ & $\begin{array}{l}\text { Teacher / } \\
\text { Document Analysis }\end{array}$ \\
\hline $\begin{array}{l}\text { (2) } \\
\text { Implementation of } \\
\text { learning process }\end{array}$ & $\begin{array}{l}2.1 \quad \text { Requirement for } \\
\text { implementation of learning } \\
\text { process } \\
2.2 \text { warming up activities } \\
2.3 \text { core activities } \\
2.4 \text { closing activities }\end{array}$ & $\begin{array}{l}\text { Teacher, Students / } \\
\text { Observation }\end{array}$ \\
\hline
\end{tabular}




\begin{tabular}{|c|c|c|}
\hline $\begin{array}{l}\text { (3) Assessment of } \\
\text { learning } \\
\text { achievement }\end{array}$ & $\begin{array}{l}3.1 \text { Assessment on the } \\
\text { learning process } \\
3.2 \text { assessment on the } \\
\text { learning achievement }\end{array}$ & $\begin{array}{l}\text { Teacher, Students / } \\
\text { Observation }\end{array}$ \\
\hline $\begin{array}{l}(4) \\
\text { Self-development } \\
\text { activities/extracurric } \\
\text { ular }\end{array}$ & $\begin{array}{ll}4.1 & \text { self-development } \\
\text { activities } & \\
4.2 \quad \text { students' } & \\
\text { motivation } & \text { on } \\
\text { development activities } & \end{array}$ & $\begin{array}{l}\text { Students / } \\
\text { Questionnaire }\end{array}$ \\
\hline $\begin{array}{l}\text { (5) supervision and } \\
\text { evaluation }\end{array}$ & $\begin{array}{l}5.1 \text { monitoring of teachers' } \\
\text { attendance by the school } \\
\text { principal } \\
5.2 \text { supervision of learning } \\
\text { process by the school } \\
\text { principal } \\
5.3 \text { evaluation of learning } \\
\text { process by the school } \\
\text { principal }\end{array}$ & $\begin{array}{l}\text { School principal, teachers / } \\
\text { Document analysis }\end{array}$ \\
\hline
\end{tabular}

Table 4. Data Source of Product/Output

\begin{tabular}{|c|l|l|}
\hline \multicolumn{1}{|c|}{ ASPECTS } & \multicolumn{1}{|c|}{ INDICATORS } & \multicolumn{1}{|c|}{$\begin{array}{c}\text { DATA SOURCE/ } \\
\text { DATA COLLETION } \\
\text { INSTRUMENTS }\end{array}$} \\
\hline \multicolumn{1}{|c|}{$(1)$} & \multicolumn{1}{|c|}{ (2) } & \multicolumn{1}{|c|}{ PRODUCT / OUTPUT } \\
\hline $\begin{array}{l}\text { (1) Academic } \\
\text { Achievement }\end{array}$ & $\begin{array}{l}1.1 \text { average subject grades } \\
\text { meet the SKBM standard } \\
1.2 \text { percentage of students' } \\
\text { success in National } \\
\text { Examination }\end{array}$ & $\begin{array}{l}\text { School principal, teachers / } \\
\text { Document analysis, interview } \\
\text { guideline }\end{array}$ \\
\hline $\begin{array}{l}\text { (2) Non-academic } \\
\text { achievement }\end{array}$ & $\begin{array}{l}2.1 \text { implementing the daily } \\
\text { worships } \\
2.2 \text { memorizing at least 2 } \\
\text { juz of the Al-Qur'an } \\
2.3 \text { emergence of discipline } \\
\text { attitude } \\
2.4 \text { Noble characters } \\
2.5 \text { master certain skills }\end{array}$ & $\begin{array}{l}\text { Teachers, students, parents / } \\
\text { Document } \\
\text { questionnaire, observation }\end{array}$ \\
\hline
\end{tabular}




\section{Evaluation of Management:...(Khasanah)}

In order to obtain the indicators for this research data using the CIPP evaluation model, Farouk and Djaali (2007: 74) suggest to use the survey research method. ${ }^{10}$

The instruments used in this data collection are: (1) observation guideline, (2) interview guideline, (3) document analysis, (4) questionnaire.

Validity test of the instruments are carried out by discussing them with several experts and are consulted with advisors. From these consultations, the items that are considered have not met the standard are revised.

This research takes place at SDIT Al-Hikmah Bangka. The research was carried out from April 2015 to June 2016. This site is chosen due to there has not been any research or evaluation carried out on the management of this SDIT. SDIT Al-Hikmah Bangka is among one of the earliest SDIT established in Jakarta.

\section{Research Method}

A) Context Investigation result on the context of evaluation is divided into three aspects. Evaluation of the government

10 Farouk Muhammad dan Djaali, Metodologi Penelitian Sosial (Jakarta: Restu Agung, 2003), p. 74 policy and SDIT, objectives of SDIT, and public demands on SDIT. Based on the analysis on those three aspects, it is concluded that evaluation is on high actuality. This conclusion is reached due to all the three aspects in this evaluation of context are met. In line with criteria of successful evaluation, namely, having the government's policy document on education, having policy document on SDIT, having clear formulation on SDIT objectives, and try to socialize the objectives, and there is a correlation with the public needs.

This research that are conducted on the government policy document and SDIT, objectives of SDIT, and analysis of public demands on SDIT, it can be stated that there is no specific policy on SDIT that can be found in the government policy for elementary education level. Nevertheless, this SDIT has unique characteristics that are in line with the government policy for compulsory education. The policy of Integrated Islamic School Network (JSIT) is that SDIT has to implement holistic education since early childhood by adding the value of the Quran and implanting the Islamic values. Government needs to adopt this kind of 
SDIT policy considering the on growing public demand on SDIT.

B) Input

Findings on input evaluation are classified into several aspects: students, parents' support ability, school financing, curriculum of educational unit level (KTSP), teachers and educational staffs, learning facilities and infrastructure, and school administration.

Students who are enrolled in the SDIT have followed the selection process based on several criteria set by the new students enrollment. Number of students in each class has not met the standard of class set by the Office of Education yet, due to the space constraint. Therefore, school needs to be more firmed on setting the limit number of students that can be enrolled in the school based on the availability of classrooms. School also need to consider that students will need space to sufficiently explore.

The SDIT al-Hikmah is sufficiently funded by the available source of funding. Therefore, it is concluded that the school financing is in high category.

Parents' support is also in high category because socio economic condition of parents in SDIT is very sufficient to fund their children education at SDIT.

School financing is also sufficient based on the findings on funding allocation that are sufficient for routine expenditure and school development. The school expenditure is sufficiently fund from currently available source of funding. Therefore, it is concluded that school financing is in high category.

Evaluation of curriculum shows that the aspect evaluated is within the success indicator, in which KTSP is used, the syllabus and lesson plan is developed, local content is accommodated within the curriculum, and self-development activities, and curriculum actualization are all in high category.

On the number of teachers and educational staffs, the majority of teachers at SDIT Al-Hikmah have 27 hours per week as their teaching load as stipulated by the ministry of education standard. The teacher to students ratio is $1: 11$, and still within the standard ratio of 1:18. Large proportion of teachers hold bachelor degree (s1), however, not all the teachers teach the subject that meet their educational background. School administration is complete and educational staffs are available based on 


\section{Evaluation of Management:...(Khasanah)}

the students' needs. These all implies that the teachers and educational staffs existence in SDIT Al-Hikmah is within the high category.

Learning facilities and infrastructure at SDIT is within high category based on the inventory on the field. Other thing that has to be mentioned is the limitation of sports field in the school due to space constraints.

Finally, on school administration, it is also within the high category because based on observation and inventory listing, the school appears to have complete administration and inventory. This result is also backed up by the assessment of Accreditation Agency of DKI Jakarta Province where this school achieves $A$ accreditation (very satisfactory).

\section{C) Process}

Based on the analysis on the process components, it can be concluded that the learning process at SDIT AlHikmah is within the high category because three out of five evaluated learning process components are within the high category, such as, implementation of learning process, assessment of learning achievement, monitoring and evaluation. Whereas, two components are within moderate category, the designing of learning process, and self-development /extracurricular components. The high category found in learning actuality is still considered bias due to the research situation. Most teachers have found in advance about the research from the deputy principal of curriculum on the coverage of teaching and learning process in the class.

D) Product

Investigation on product components reveals that academic achievement, that is the grades at UASBN (National Examination) is in high category due to A predicate (very satisfactory) grades that the students achieve for Mampang Prapatan subdistrict compared to other schools, with the average marks in three subjects of UASBN is 7.57, and that all the students passed the examination to pursue higher level of education. This high academic achievement cannot be separated from the efforts of the grade 6 teachers to conduct extra hours learning guidance, from 14.15 - 15.30 western Indonesia time. For those who achieved low marks in mathematics during their first semester 
in grade 6 , they are required to take extra hours in semester 2 that are conducted on Saturday, from 8.00 am to $10.00 \mathrm{am}$. These are how students are prepared to participate in UASBN, other form is through several tries out conducted by the school or in cooperation with other parties, and also in coordination with JSIT to determine the minimum standard of achievement. Finally, based on the achievement in this try out and agreement with parents, the minimum standard grade for learning in Bahasa Indonesia, Mathematics, and Natural Science is decided to be 4, 3, 3 .

The non-academic achievement is in moderate category, because out of five aspect evaluated, that is their worships, Quran memorizing, discipline, noble characteristics, are all within the moderate category, except for skill aspect that is within the high category.

\section{Summary}

\section{Context Evaluation}

Based on three focus of context that consists of government policy, objectives of SDIT, and needs analysis, it can be concluded that the evaluation of context is within high category.

\section{Input Evaluation}

Based on the description of input components that consists of seven aspects, in which all of them are within the high category, therefore it is concluded that the input components are within high category.

\section{Process evaluation}

From the findings and discussion on process components above, it is clear that all the learning process in SDIT AlHikmah is within the high category.

\section{Product Evaluation}

The characters of the students in SDIT is within the moderate category. Therefore, it is noted that there is a need of continuous guidance and teaching of good values to students as well as individual guidance for those who need it.

Actualization of skill mastery is within the high category, as expected. 


\section{DAFTAR PUSTAKA}

Alaydroes, Fahmy. 2008. Latar Belakang, Visi dan Format Sekolah Terpadu. P.1-3.

Arikunto, Suharsimi. 2006. Dasar-Dasar Evaluasi Pendidikan, Jakarta: Bumi Aksara.

Arikunto, Suharsimi dan Cepi Safruddin Abdul Jabbar. 2004. Evaluasi Program Pendidikan, Pedoman Teoritis Praktis Bagi Praktisi Pendidikan. Jakarta: Bumi Aksara.

Groundlund, Norman E. and Robert Linn. 1990. Measurement and Evaluation in Teaching . New York: MacMillan Publising Company.

JSIT Indonesia. 2006. Sekolah Islam Terpadu Konsep dan Aplikasinya Bandung: Syaamil Cipta Media.

Muhammad, Farouk., Djaali. 2003. Metodologi Penelitian Sosial. Jakarta: Restu Agung.

Nata, Abududdin. 2007. Manajemen Pendidikan, Mengatasi Kelemahan Pendidikan Islam Di Indonesia.Jakarta: Kencana Prenada Media Grup.

Popham, W. James. 1974. Educational Evaluation, Englewood Clifts, New Jersey: Prentice-Hal Inc.

Worthen, Blaine R dan Sanders, James R. 1987. Educational Evaluation, Alternative Approaches and Practical Guidelines. New York and London : Longman Inc. 